\title{
An Analysis of Reports from the Office of the Auditor General of Canada: How Audit Guidelines Shape the Documents that Inform Government and Citizens
}

Laura Palmer, Ph.D.

Candidate in Technical Communication and Rhetoric

Department of English, Texas Tech University

Cet article présente lanalyse de deux rapports de vérification produits par le Bureau du vérificateur général du Canada (BVG) au cours de l'année 2000. Ces rapports sont examinés à la lumière du Manuel de vérification de loptimisation des ressources, la publication qui guide la procédure de vérification et qui, en fin de compte, détermine la forme que prendront ces documents avant dêtre portés à l'attention du Parlement et du grand public. Lanalyse menée démontre que le Manuel de vérification de l'optimisation des ressources, lévaluation de l'entité publique et la révision de la hiérarchie organisationnelle du BVG concourent à produire des documents qui varient passablement sur le plan de leurs pratiques détablissement de rapports. En outre, la présentation des rapports eux-mêmes est prise en compte puisque cet aspect contribue à réduire l'intelligibilité de l'information. Cet article soutient que les messages importants contenus dans les rapports sont construits si rigoureusement et intégrés dans des présentations graphiques si complexes qu'il est difficile, tant pour le gouvernement que pour le grand public, détablir si une évaluation est précise et consciencieuse.

This paper examines two audit reports produced by The Office of the Auditor General of Canada (OAG) in the year 20oo. These reports are reviewed as compared with the Value-for-Money Audit Manual, the publication that guides audit practices and ultimately shapes the final communication before it becomes both a parliamentary and public document. The analysis conducted demonstrates that the Value-for-Money Audit Manual, the rating of the government entity, and the review hierarchy of the $O A G$ conflate to produce documents that vary substantively in their reporting practices. Additionally, the document design of the reports themselves is considered as this feature 
serves to lessen the readability of the information. It is asserted in this paper that messages of importance in the reports are constructed so carefully and situated in such a visually complex design that it is difficult for both government and the public to determine if an assessment is fair and honest.

The Office of the Auditor General of Canada (OAG) is vested with the responsibility for monitoring and reporting on the operations of the Government of Canada, its Crown corporations and other entities. In order to make assessments and provide information to both the government and the citizens of Canada, the OAG regularly conducts audits on operations. An audit-as a detailed review of an operation-is framed by the OAG in its 2004 definition as

a systematic, purposeful, organized and objective examination of government activities. It provides Parliament with an assessment on the performance of these activities; with information, observations and recommendations designed to promote accountable government, an ethical and effective public service, good governance, sustainable development and the protection of Canada's legacy and heritage.

(Performance Audit Manual, 2004, p. 13)

The audit data derived from the OAG's review becomes a communicative vehicle in the form of a document released to both the public-at-large and Parliament. These reports-called 'chapters' in OAG nomenclature-examine key operational areas on a regular basis and are used as a mechanism to report to Parliament. They become the starting point, in many cases, for developing administrative policy and political legislation. The reports, while not limited to these general areas, concern themselves particularly with evaluations of fiscal management, essential record maintenance and effective implementation of policy and programs. These reports are, by far, one of the most important documents written for the dual purpose of informing citizens regarding the country's standing and directing the actions of government. However, what most individuals know about the processes and procedures that ultimately shape the creation of these reports is limited; audit reports do not have the kind of compelling cachet that results in either casual reading or a profusion of academic analyses.

\section{Significance of this Analysis}

In order to frame the analysis presented here and, ultimately, gain a greater understanding regarding the workings of government and its legislative and policy-making functions, I believe it is crucial to explore the formation of this specialized genre of reports generated by government auditors from their assessments and evaluations of 
the country's operations. As an over-arching approach to the topic of OAG reports, I embarked on this analysis with the following questions in mind:

- What do we know about reports generated by the Office of the Auditor General?

- What informs their creation; what documents serve as guides?

- How is information ultimately conveyed to the public and the government?

- Can the reports be trusted to transmit information fairly?

- Do these documents have sufficient exigence to generate appropriate social action?

The purpose of the analysis conducted here is to examine the primary document that shaped audit reports in Canada during 2000-the Value-for-Money Audit Manual (VFM); in addition, this analysis also considers the VFM as juxtaposed to the hierarchical review process of the OAG and the document design of its audit reports. As the reports of the OAG are the most influential instance of assessment and recommendation for the country, two of the reports from the spring of 2000 will be used to demonstrate how the reporting conventions are shaped by these multiple exigencies and how the final message is formed.

By examining the audit manual, the review process and the design of the report documents against two operational audit reports, this analysis will demonstrate that clear and unbiased communicative goals become obfuscated by the over-arching requirement to shape and display the audit report in specific ways. This crafting of the message by the OAG serves to create a genre that does not engage social action in the sense intended by Carolyn Miller in 1984. Rather, reports of the OAG-as documents produced by and for government and citizens alike-become a specific genre whereby social action is constrained or mitigated by the very systems that guide their creation.

\section{Framework}

Considering their function within Canada's parliamentary processes, the OAG presents a unique and largely unexamined instance of reports and the factors that conflate to shape them. While reports, as a general subject for study, receive a considerable amount of attention in terms of pedagogy, academic analysis and professional development, these documents-as related to government or public policy-are not regularly studied. As aptly noted by Carolyn Rude (1995) in her article, "The Report for Decision-Making," scholars prefer to examine more compelling documents; consequently, public-sector work remains, for the most part, overlooked.

As a genre, audit reports are influential transmitters of information; of course, this holds especially true for a document that would inform a government on the operations of a country. Yet, because such documents have received so little atten- 
tion from the academy, our understanding of their creation and function is limited. When reflecting on the accounting profession-and, specifically, the practice subset of auditing-it is not common to associate an analysis in the form of a narrative. Audit summaries, in the minds of most, are presumed to be synopses of ledgers and discussions of a company's financial status. The audience for this information-shareholders and board members-then uses the information to make active determinations about dividends and directions for the company. Synoptically, such summaries are considered to be based on the tangible aspects of the red or black bottom line; their final purpose remains to present facts with respect to an obvious "choice about action" regarding monetary matters (Rude, 1995, p. 181).

However, auditors base their assertions on more than straightforward fiscal prognostications and predictors. Their analyses often include an intense scrutiny of operations for efficiency in both processes and procedures; such analyses can make the concept of action - when not fiscally predicated-less transparent. What becomes transmitted in an audit report is therefore not always numerical; rather, it is a structured and recurrent rhetorical narrative of a company's overall performance in areas beyond the balance sheet. These reports are generated in a variety of auditing practices within the accounting profession: public practice, internal audit, and the specialized subset of internal audit-government audit-all produce written materials in the form of reports that are designed to elicit action(s).

Enigmatically, though, audit reports like those written by the OAG may not produce action in the way Carolyn Miller originally conceived of in her 1984 article, "Genre as Social Action." Miller's focus on genre was centered on "the action it is used to accomplish" (p. 151) with her tacit assumption being that "action" was an all or nothing proposition that would be transparently clear should a document meet the criteria consistent with her genre claims (p. 163). Consequently, if an audit report from the OAG cited a problem and made recommendations, its true effectiveness as a rhetorical genre would result in action(s) at multiple levels that seek to remedy the shortcomings.

Miller's (1984) model, though, may have failed to take into account the way specific communicative forms, like publications produced by branches of government, need to perform as informational documents. Miller came close to establishing the uniqueness of these documents in her assessment of environmental impact statements; however, what she, at the time, called a failed genre claim with respect to the environmental statements was not an accurate descriptor of their function. Instead, this type of government document - shaped by needs and constraints not obvious to outsiders-can act as a genre specific to structures of large organizations such as governments. The conflicting interpretative contexts and insufficient fusion of substance and form may not constitute a failure, as Miller originally postulated, but the genre 
required by and of an organization seeking to reduce the affect, risk and transparency of its communications (p. 164).

This reduction of affect in public sector documents is key to the understanding of them as unique. While little academic work has been conducted on public sector documents, research frames these communicative modes as having characteristics that do not necessarily facilitate Miller's desired outcome of action. Susan Kleimann (1993), in "The Reciprocal Relationship of Workplace Culture and Review," studied the document review process in the American equivalent to the OAG, the General Accountability Office (GAO). As per its Canadian counterpart, this American office also deals with reports that can influence "national policy"; additionally, the "conservative culture," as Kleimann calls it, mandates that their written products speak "with the voice of the agency, not of an individual or an individual group." In short, GAO documents must meet the organization's requirements for "balance, objectivity, tone, adherence to organizational priorities, consistency with image and values, and a range of other complex and subtle points" (p. 58). That social action then becomes a nuance rather than an exigent requirement is a forgone conclusion.

As documents are, as noted previously, shaped internally to ensure the message is right, then understanding the organizational requirements becomes a matter of examining the collateral materials that result in the production of institutional knowledge. Anthony Parés (1993) study of social workers' writing in "Discourse Regulations and the Production of Knowledge" made explicit the multiplicity of factors that contribute to the type of message to come from the organization. For Paré, however, writing in governmental contexts requires not just an analysis of the final artifact but also knowledge of "how style guides, writers' manuals and other discourse regulations determine the production of knowledge" (p. 123). These collateral documents and their function of shaping, conveying and displaying the message, according to Paré, require further study to understand how they influence the public document. To that end, this analysis will consider the guiding manual, organizational hierarchy and document design as they conflate to shape the message in Canadian OAG reports.

\section{Methods}

As a means to provide insight into the practices that result in Canadian OAG reports, this analysis examines three documents from 2000. The guiding document for the conduct of a governmental audit in Canada was the Value-for-Money Audit Manual (renamed the Performance Audit Manual in 2004). Written in conjunction with the Institute of Chartered Accountants of Canada, this manual defines not only the standards and best practices of the auditing process but also the nature of the reporting. It is, in effect, the vehicle that drives the rhetorical focus and genre of OAG reports.

The two reports reviewed in this analysis are audits of what the OAG refers to 
as entities. An entity, in the nomenclature of the OAG, is a department subject to reviews or audits as deemed necessary by the office. These reports, Chapters 7 and 8 respectively from the year 2000 , are evaluations of two major operational entities in Canada: The Department of Finance and the Royal Canadian Mounted Police. They were selected due to their similarities as operational entities and the stark contrast of their rating by the OAG.

In the rhetorical analysis that follows, the VFM and its contradictions and conflicting reporting conventions are considered. Next, the organizational hierarchy that influences the messages in the reports is discussed. To demonstrate how the manual and the organizational shaping of the message occur, several important differing conventions between Chapter 7 and Chapter 8 are highlighted. Finally, the visual design of the documents - as a rhetorical function of the OAG reports - is considered here. While not driven by VFM guidelines, how the reports are presented visually to their general readership and how this may influence that readership are discussed.

\section{Guidance from the Value-for-Money Audit Manual}

The 2000 VFM manual spans 80 pages and was the first part to be completed in a three manual comprehensive series (the Annual Audit and Special Examinations manuals were still in development in 2000). The VFM determines how an audit is conducted and delineates the ways and means by which a report achieves compliance with the VFM standards. Specifically, the VFM defines key elements of the reports including fairness, objectivity, bias, tone, persuasiveness-all of which conflate to create a report that then is explicitly reviewed as to whether or not "the message is right" (p. 21). Multiple levels of scrutiny from both the OAG's office and entity management ultimately result in a report that has clearance to become both a parliamentary and a public document. According to the 2000 version of the manual, a VFM audit report is

a systematic, purposeful, organized and objective examination of government activities. It provides Parliament with an assessment on the performance of these activities; with information, observations and recommendations designed to promote answerable, honest and productive government; and encourages accountability and best practices. (p. 4)

However, the VFM manual attaches strong caveats to its overall mandate of honest, objective reporting very early in the document. On page 6, the VFM clearly states that "audits do not question the merits of the government's programs and policies," only their implementation. Furthermore, auditors are warned it would be best if they did not present information that was too controversial. "Caution is necessary" as the Auditor General may become part of an undesirable partisan political debate that is 
beyond the scope of the office's mandate. This, the manual deems, "would be very risky" for the OAG's office as a whole (VFM, p. 6).

While the VFM mandates the audit reports to "deliver clear, persuasive and effective communications" to Parliament, risk is a recurring concern for the reporting standards and acts as a mechanism to flatten the affect of the report (p. 23). "Special care is required when audit findings touch on government policy" (p.5) as the OAG is worried about the "loss of reputation" to the entity or the Office (p. 29). Moreover, auditors are instructed by the VFM that in instances where risk may be a factor, they are to ask themselves "Can the risk be minimized or controlled?" (p. 29). The emphasis concerning risk is to discourage the auditors from pursuing an avenue that may be contentious at a national level.

\section{The VFM and the Hierarchy of the OAG}

The sway of the VFM-as it guides the creation of OAG reports-serves to produce artifacts that limit action and follow the instrumental rationality typified by bureaucratic organizations. In the terms of Killingsworth and Palmer in their 1992 article, "The Environmental Impact Statement and the Rhetoric of Democracy," manuals like the VFM result in "a narrow path of action" that becomes limited even more so by the "hierarchically arranged powers" of the organization (p. 166). This hierarchy of power as it drives the creation of knowledge in the form of the report review process serves to constrain what is presented and downplay issues deemed too critical to appear in print.

As Kleimann (1993) noted in her examination of the document review processes at the GAO, documents pass through multi-tiered processes within the organization that culminates in the production of an artifact that is the voice of the agency. As per the GAO, OAG reports such as the RCMP and the DoF examined as part of this analysis passed through an almost unfathomable number of hands before being released as public documents. Every level of the OAG's office reviews the report, and the entity in question is furthermore permitted to evaluate and modify the document. This becomes, in Kleimann's terms, the hierarchical review process so prevalent in government and the second mechanism by which the affect of the final artifact becomes flattened.

As shown in Figure 1, OAG reports are composed by the Report Group. Based on the audit documentation and the VFM guidelines, the Report Group compiles the audit notes and develops the first draft of the document. The Report Group is simultaneously guided by the Report Steering Committee who approves "strategies" as per the VFM and governs the themes and length of the chapters (p. 12). The next level in the report generation protocol sees the Director(s) preparing chapter drafts for submission to the Principal who reviews all drafts and chapters. After review at the directorial level, the report makes its way to the Second Assistant Attorney General 
who specifically checks the "compliance of the chapter with the reporting standards" outlined in the VFM (p. 15).

The fifth, and not yet final level of review, occurs in the office of the Assistant Auditor General. This office reviews and challenges the report chapter and clears the report with "senior entity officials" of the area under review as without the approval of the entity in question, the report will not proceed any further (p. 15). Finally, the sixth

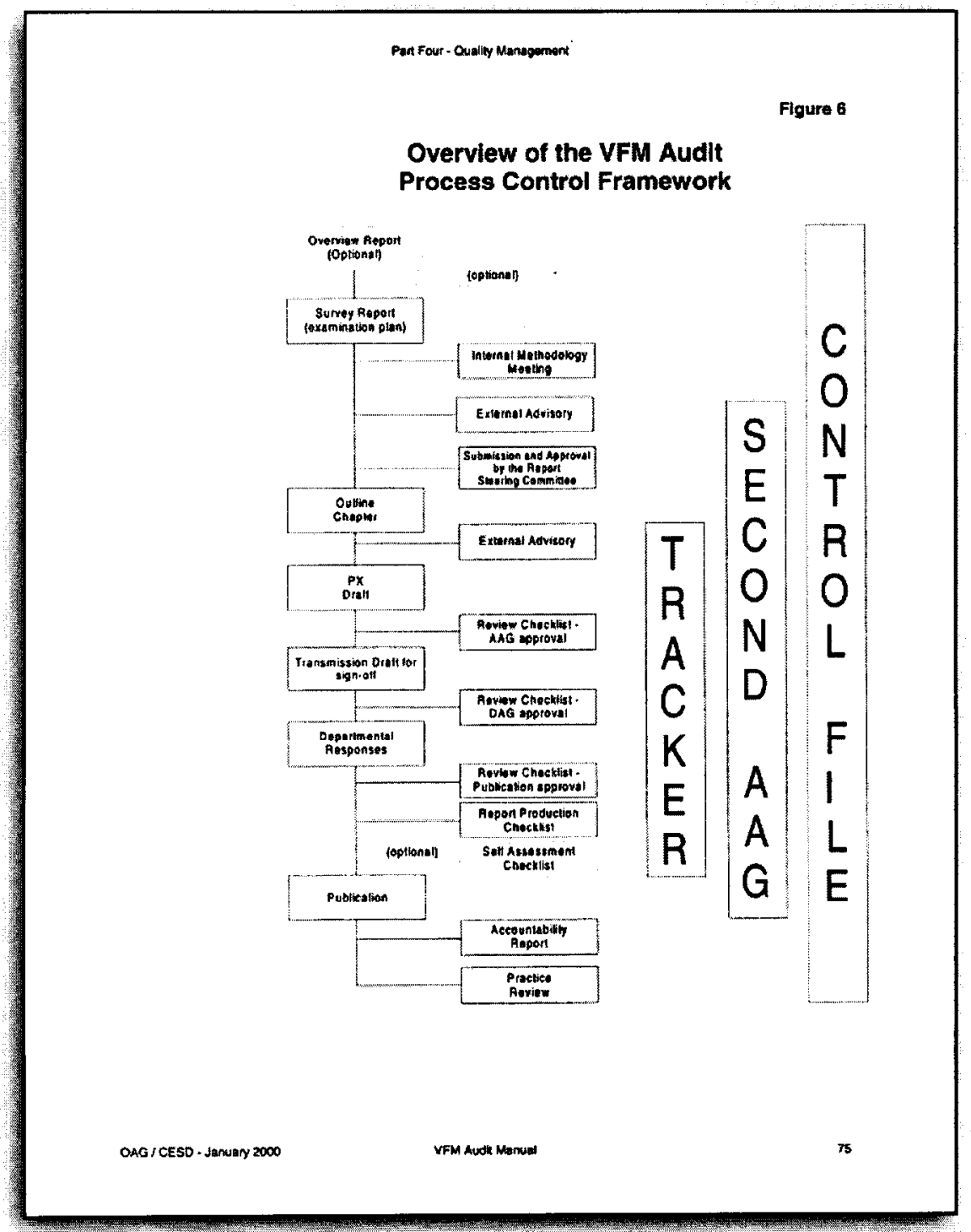

Figure 1. Audit process control frame (VFM, p. 75) 
and last stop for the report is the Deputy Auditor General who "reviews all chapters prior to publication to ensure that the messages they contain are consistent with previous Office positions" (p. 16). This office provides the final sign-off and permits the document to become available to both Parliament and the public.

\section{The Reports-Chapters 7 and 8}

In early April of 2000, nine entities were the subject of an audit and the resulting reports, called "chapters" in the OAG's terminology, were released. The focus of this analysis considers two of these reports and examines how they are shaped by the VFM, the review process and ultimately, how information is presented via the design of the documents. The chapters, "Chapter 7: Royal Canadian Mounted Police Services for Canada's Law Enforcement Community" and "Chapter 8: Department of Finance Managing Canada's Debt: Facing New Challenges" are discussed here for their general tone. Specific instances where critical issues are downplayed follow.

\section{The Royal Canadian Mounted Police}

The RCMP was the subject of an OAG audit in 1990, and the report examined in this paper was the first to appear in nearly a decade (p. 7-5). In 1990, critical areas were identified in which the RCMP was not providing the appropriate levels of service. In this 2000 release of the OAG's report, the RCMP was not well appraised in the audit and was vilified by the media-a public consumer of OAG documents. The document summary of this chapter, entitled "Main Points," opens with paragraph 7.1 and the statement,

The levels of service that the RCMP provides to the Canadian law enforcement community do not meet the needs of its clients. (p. 7-5)

The audit, in summarizing the 1990 conclusions and comparing them to the April 2000 findings, was very critical of the RCMP and states, "We made a number of recommendations [in 1990] to improve operational economy and efficiency. Attention has only recently been paid to many of our recommendations and others have not been addressed" (p. 7-5).

Unequivocally, the RCMP was not performing well and had done little, if anything, to implement the recommendations of almost a decade ago. At the time, the RCMP was deemed to be deficient in the operational areas of forensics, computer information systems and criminal records services. Additionally, their internal records were shown to be neither accurate nor up-to-date and serious questions arose about how the RCMP chose to spend its fiscal allocations. 


\section{The Department of Finance}

The Department of Finance (DoF) is responsible for managing Canada's federal debt, particularly its organization and borrowing program. Debt, in this instance, is a measure of the economy both domestically and internationally as related to the government's fiscal policy for incurring debt. Debt management does not, however, "deal with the size of the debt." Instead, debt management "relates to the ways the government raises funds to meet its financial requirements, what it decides and does about the composition of the publicly held debt, and how it governs these activities" (p. 8-7).

In 1996, the DoF was the subject of an audit report on federal debt management. The report was the product of a series of five-year studies conducted throughout the 1970 and 1980 s that monitored "rising levels of federal debt and volatile interest rates" which in turn, resulted in the "government's credit rating" being lowered ( $\mathrm{p}$. 8-7). The report, released in April 200o, presented the DoF in a different light-now the audit concerns were related to debt surplus, not acquisition. Not surprisingly, the government's reversal of fortunes could easily be construed to preordain the auditor's conclusion that the DoF was well run. In support of that assertion, the auditor's "Main Points" summary, paragraph 8.1 states,

Canada's debt management program is a well-run operation overall...the people who manage this program are a highly committed group. (p. 8-5)

The most cautionary comment from the audit report concerned the Department's ability to manage a surplus situation. After so many years of managing a deficit, the audit indicated that the DoF might not have the necessary strategies in place for this situation. Still, the DoF was given only three recommendations: increase their performance measures; ensure public accounting has both a cost and benefit analysis component; and, modify the management of strategic planning. There were no serious flaws in the audit's assessment about the operations of this department.

\section{Downplaying Significant Issues}

Both the VFM and the review process of the OAG serve to limit what is expressed in the reports. As an example, the RCMP's deficiency with respect to rapid forensic analysis (DNA results) and the impact on the execution of justice is kept almost exclusively to quantified issues of cases and turnaround times. The Bernardo inquiry is mentioned, and it is noted that "the suspect committed four more rapes and two murders" due to the slowness of the RCMP in providing DNA analysis (p. 7-10). Human consequences, however, are never mentioned again and the next six pages of the RCMP report cite only statistical findings related to the case.

The DoF report also downplays an area of importance-the actual relevance of 
Canada's national debt at the time. Like the RCMP's report, the DoF's audit does not starkly measure its outcomes with a human factor. Neither the fact that fiscal mismanagement of national debt financing could easily plunge the country into an economic tailspin nor the devastating effects such an event could have on Canada's citizens is discussed. It would seem the overall positive nature of the report negates the audit expressing consequences in more cautionary terms. As an aside, Canada was second, in 2000 , only to Italy in its ratio of debt to gross domestic product for $\mathrm{G}-7$ countries - at the time, the country was by no means in a position of economic solidarity.

The DoF report summary immediately identifies Canada’s national debt as “ \$595 billion," but as no other contextual elements were provided as a framework for interpretation, the figure is an abstraction (p. 8-5). Three pages later, the report mentions that the "debt-to-GDP ratio" is 62.6 percent, but a hard dollar figure for comparison is not provided (p. 8-8). Through the separation of facts, the OAG's reports devise their own form of instrumental rationality. While the VFM clearly states that "relentless attention by the auditor is needed to identify and focus the audit on the critical operations," the nature of how critical information will be conveyed is predetermined, it would appear, by the operational success or failure of an entity (p. 33).

Conflict Resolution with Entity Officials

The VFM discourages discord between the entity examined and the OAG's report. Thus, rectifying disagreement is an integral part of the review and approval process. The auditors must, according to the VFM, "seek entity management's views about critical elements of the audit" (p. 19) and correct "any disagreement with the report" (p. 20). What comes into question from the above is how the report maintains the required "objectivity and independence" when it is subject to both the strictures of the VFM and multiple levels of review and revision (p. 17). For the most part, the VFM serves to generate a homogenized government document bereft of divisive content.

While it is undoubtedly impossible to suppress all disagreement in an audit report, the VFM certainly limits its expression. The reports are, according to the VFM, required to make allowances for the publication of departmental comments. Departmental responses to recommendations or concerns are encouraged, and those responses containing an element of "agreement" have no limits placed on their length or scope. Disagreements, on the other hand, are permitted with only "a brief explanation" (p. 42).

As the RCMP agreed entirely "with the findings" of the OAG's report, they were permitted two and a half pages of explanatory comments immediately after the document's conclusion. In this section, the RCMP explain how they believe their shortcomings evolved and establish means and measures to improve the situation ( $p$. 7-5). The DoF, however, approaches the OAG's report with a much less passive stance. Their response summary in the "Main Points" section states that for "the most part, the 
Department accepts the thrust" of the audit recommendations; however, they rebut quite readily at any point with which they have even minimal disagreement (p. 8-6). The DoF's rebuttals tend to be quite lengthy and defensive and perhaps, because they were well rated, the DoF felt they had more liberty to be argumentative.

Notably, the DoF report is given latitude denied the RCMP and, again, conjecture arises about whether this provision was made due to their good review. The VFM succinctly states, "we do not print departmental responses or comments in the Main Points or throughout the chapter" (p. 43). Yet, the DoF report is replete with departmental responses in the chapter.

\section{Document Design}

The reports originating from the OAG's office are considered both public and parliamentary documents. Their function is to provide accountability to the people of Canada for the actions of its government. As these reports are public documents, it then becomes possible to question if they have a defined visual rhetoric as executed by document design that invites general review and commentary. The VFM, while being the authoritative piece for audit reports and their content, does not include guidelines with respect to layout and visuals; however, as Paré (1993) notes, an organization like the OAG will have an in-house style manual that governs the conventions of their document design.

Charles Kostelnick and Michael Hassett (2003) in Shaping Information: The Rhetoric of Visual Conventions state with respect to the visual design of documents governments "often standardize their publications to certify their authenticity and to ensure readers that they are credible sources of information" (p. 111). In fact, Kostelnick and Hassett indicate "in-house style guides that simplify the design process" (p. 85 ) are necessary for making explicit at an internal level how "organizations" such as the OAG shape their communicative conventions (pp. 81-82). However, what such guides do not necessarily make overt are the "material and political conditions that regulate and shape the conventional practices" and how these are manifested in the final artifact such as a report (p. 83).

Kostelnick and Hassett ( 2003 ) have found that the conventions of any visual language - such as the internal guidelines for document design - are shaped by organizations in ways that adhere to or ignore the standards of best practices simultaneously ( $p$. 6). While visual genres such as the design of a report are formed by what Kostelnick and Hassett refer to as the exigency to "structure information [and]...stylize it" (p. 99), such design conventions can be ineffective ( $\mathrm{p}$. 197) and can serve to limit readers' comprehension of "intended meaning" or "intentionally misdirect readers" with respect to the content (p. 210).

Thus, a consideration of the visual rhetoric of the OAG's documents can provide 
insight into how these documents work to convey information. Sonja K. Foss in her 2004 chapter, "Framing the Study of Visual Rhetoric: Toward a Transformation of Rhetorical Theory," describes visual rhetoric as a "theoretical perspective that involves the analysis of the symbolic or communicative aspects of visual artifacts" (p. 306). Most significantly, though, Foss is less focused on how scholars or design professionals may view a document; rather, she finds it important to consider design from the perspective of "lay audiences" (p. 306). Therefore, the analysis provided here will follow her analytical framework whereby an understanding of visual rhetoric is derived from an "explication of the distinguishing features of the visual artifact itself"(p. 307).

Paré (1993), as well as Kostelnick and Hassett (2003), enumerate how organizational guides and conventions shape the design of documents; however, guidance from the VFM with respect to design is negligible in this respect. In terms of page layout and the development of what Foss calls "distinguishing features," the only reference to the overall appearance of a chapter is found on page 32 of the VFM where it is indicated audit documentation should be "structured for easy access." Discussions of graphical elements and the guidelines governing them receive the same degree of brevity, and audit teams are instructed to contact unnamed "other support groups" for advice on "report style and use of graphics" (p. 22).

As the reports are shaped by documents not part of the public domain, an examination based on Foss's (2004) concept of distinguishing features and lay audience is one means by which to better understand the OAG artifacts. Both Chapter 7 and 8 are 29 pages in length, and a review of other reports in the series indicates this is about average for an OAG's report. Common to all reports in the series is their page layout and typography. As per Figure 2, summary pages or "Main Points" span the page width while body pages are structured so that each page consists of a two and a half column layout with two left justified columns for text and a half column on the outside margin for incorporating callout text. Top and bottom margins include running header and footer information.

TyAnna K. Herrington (1995), in her article discussing graphical presentation in a U.S. government report authored by the Bureau of Alcohol, Tobacco and Firearms, states that there is power in "type size, textual font and style choices, and placement of text" (p. 154). This power, she states, influences readers' comprehension of the material and, certainly, the OAG could be viewed as using such a mechanism to make their documentation less inviting and, in turn, subject to reduced scrutiny from the Opposition (political), governmental watchdogs, media agencies or even a lay audience such as the public. While the intent of the OAG's Office may be to make information available, their product is at odds with their purpose.

All but the most diligent of readers could be dissuaded by the appearance of an $O A G$ 's report - the visual rhetoric as conveyed by page density and design acts 


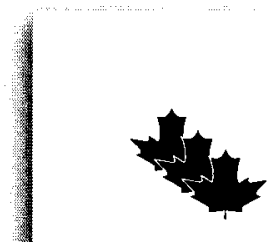

Main Points

7.1 The levels of service that the the needs of its slients. For example, provides information to police officert. nationally 11 percent of the time lest cases. Thus. its full potential for pubbe inputsing criminal histony rectords and fingetprnt data avalable to the police employers or volunteer organizationa

7.2 It is imperative that senior not services and improve efficiency. In p

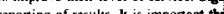
reporting of results. It is important th:

7.3 The arrangement between the tode rethoy toderal, provincial and municipal nove - Ix $x y$ Treasury Board Resourte There is a need to move forruard and to these review.

7.126 The RCMSP should conodide its rastonal services and establish operational and strategic plannim across the business line.

\section{Conclusion}

7.127 The RCMP provides a range of services that are essential to the Canadi las coffincemein contrumity. These services itwilude fingerprim identification. dina banks such as vechick registration
divers" licences. The efficiency and enfurceme it

7.128 The RCMP has taken a number of intialives to improve service. For eximpice. its effort to keep the 3)-year-old CPIC system operational and handling sessigned to do is temminemsisble. it has also introduced DNA analysis. which had a vignificam impact on polics investigations and prosecutions, and it is developing a DNA data banic and an

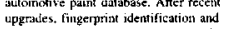

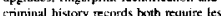
crininal history records both requite he systems in coher jurivitionos, these services contain the fingerprints and records of all crininals senterticed in Candia. Finally, the CPIC Advisory Comminee is an exiellent example of effective user input.

7.129 The levels of sertice that the RCMP protides do not meet the need univaliable 11 percent of the time. DNA

\section{Royal Canadian Mounted Police}

\section{Services for Canada's Law}

Royal Canadian Mounted Police-
Services for Canada's Law Enforcement Community

\author{
Introduction \\ 7.7 The Royal Canadian Mounted \\ Police provides a sel of national service \\ that assist members of Canada's law \\ enforcement community in their work and \\ enhance public safety. For example: \\ - Police officers need to know if the \\ car they stop is stolen. or if the driver is \\ dangerous, unstable or wanted for any \\ - The couns use the results of a DNA \\ analysis or a fingerprimt check to convict. \\ - Parole boards need to have accurate \\ information on at innates's criminat
}

- The Canadian Police College provides advanced and specialized training to police officers.

- Criminal Intelligence Service Canada gathers and shares infornation from different agencies on organized crime.

7.9 As shown in Exhibit 7.1, these national services nepresent an expenditure of over $\$ 122$ million annually (about six percent of the RCMP's spending) and account for I.169 staff (about six percent of RCMP personnel). The different services have one business plan but are primarily managed individually. Don noth - in

od on the key povides to the at community. kogistry was it to CPIC. We Royal Canzdian Molnted Police
Services for Canada's Law Enforcement Comornunity crinirial thistory reverds, forensic analys is. crnniral intelligence and on-line eccess to
dina bankis wuch as vectick registration and

analysis toles too long and is limited to only the most important cases.

cosis of police investigains to cat the realized Backloos of up to two months exist for criminal history records and fingerprints *aiting to be inpust to data bains. Therefore. the records and fingepprim dara available ot the police and others are not currenl. As well. criminal record thecks required by eimployers or

7.110 Users of the serices often carima provide input into the management of these services. For example. CPIC bas excellent advisory commintioe but forensic laboratories do not have one at all. Where hiere are suct consinices. the metribership is mainly police. although public are also users of these serviess

7.1.31 Some gertices are the nun efficiently. In forensic laboratones, cases are not prioritized. Less urgent cases are oftent complicted ahead of urgent cases. and casclowds and backlogs vary wict among the laboralones. There are rull. new laboralanies in Ottawa and Regina wilhowet thornughly aralyzing the powentid for rationatizing laboratory services and the portential bere tits.

7.132 Iremendous potential exists to strenzthen the criminal justice system by having the results of DNA analysis mututikely atailable when invesiig have just begun their work would significantly reduce investigation cosis and improve public safery.

7.133 Our 1990 audit raised questions about the tnanagemeat of these services. 3bout ine tranagement of these
the teed to rationalize forensic the tieed to rattonalize forensic the need for user input and planring for the fulure. This audit showed that ile sume coticerns sill exis
The RCMP has taken a number of initivives to improve service, but the lovels of service that it provides do not awry meet the needs of he cllenta.

Tremendous potentid exiats to strengthen the criminal juatice system by improving these services.
ACMP national services are essential to public salety. if our audit were

bas improved its haw enforcern jit has made Preas of concer fith and studies:

the RCMP has id procedures to ifficiently to the it decade. vo the audil can chapter in

id

ins

a

forensic

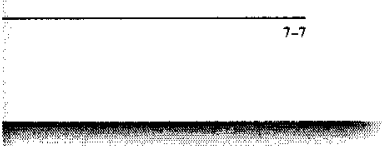

Figure 2. Sample pages from the RCMP report. 
to deflect rather than invite readership of any kind (Herrington, 1995, p. 153). The page is cluttered with a colliding mixture of body text, header/footer information, callouts and headings. Graphical clues-devices that lead the eye and subsequently the reader through a document-are difficult to follow. Bulleted text does not adhere to the convention of the hanging indent, and the numbered paragraphs use large tab spaces that actively create a disconnect between the number and the text rather than establishing cohesion (Johnsen, 2000, p. 197). The crowding of the header with the body of the document serves to congest the page and does not make use of the well-known visual delimiter of white space. As well, the callouts-a common device in journalism and informal reporting-seem out-of-character in an audit report. Their purpose and, more importantly, their content come into question; in particular, does the OAG use this larger, more prominent textual feature for specific rhetorical purposes such as biasing a reader.

The typography, a standard mix of a serif body font and a sans serif heading font, is acceptable considering that PDF is the medium of delivery. However, the use of typography in the styles of the report document is cumbersome. As an example, it is difficult to ascertain when a new section has started in an OAG report due to the awkward execution of an effective heading hierarchy. The levels of hierarchical headings are, in fact, unclear to any reader without consulting the Table of Contents as their design includes only a minimal differentiation in point size. While the rules of design are open to some degree of interpretation, The Canadian Style (1985) does note that headings in reports are a mechanism that helps the reader process the "subordination of topics" within a document and that an effect as simple as "spacing" is one way to effectively create this distinction (p. 210).

In terms of the rhetorical effect of typography and space, Karen Schriver's 1997 Dynamics in Document Design discusses how readers navigate documents based on what she calls "spatial cues" (p. 333). Space provides, according to Schriver, visual indicators that differentiate information and provide a means to more effectively process information at a cognitive level (p. 279). Balancing spatial usage is key to the success of documents as too little space can crowd information making it difficult to process, while too much can inhibit the reader's ability to establish cohesion between ideas. With respect to space, the layout of OAG is that of a dense page-one that is not necessarily inviting to read. This would seem to be a contradiction in intent, as the documents are readily available and the website encourages interested parties to download and read the materials. The VFM advocates materials that are accessible but seemingly abdicates any formal responsibility or even guidelines for their design.

The lack of page breaks for key sections also makes the document difficult to follow and the use of before/after space for paragraphs is not well executed as a spatial cue for indicating the start of a new section. While all paragraphs are numbered for easy 
reference, the overall visual effect is disjointed at best. As the OAG's Office has made these reports available to the public via the internet, their blanket visual appearance makes one question the degree of the attempt to garner readership. The dense layout, with compressed graphics, narrow column widths and other visual irregularities, only serves to increase the effort required to read the reports; undoubtedly, these features also act as a mechanism to reduce readership.

\section{Discussion}

The OAG's reports, as shaped by the 2000 VFM and the document review process, are required to "provide objective information, advice and assurance to Parliament" (VFM, p. 8). Without a doubt, Parliament and the House of Commons receive materials that reflect the operational status of government entities. Through the reports of the OAG, government will continue to enact the legislative process and ultimately national policy will be enshrined. However, how well does this material convey the facts to both government and the public? Do the authority and character of the document vacillate subtly from the reporting conventions depending on the overall findings of the audit team? Moreover, without reading the VFM or understanding the multiple levels of review, can a decision-maker or a private individual understand the forces that have shaped the content of the final document?

In assessing the VFM, the review process and the two reports discussed in this paper, what comes into question is how the DoF and the RCMP received differing treatment in the reporting system. The DoF, as a well-rated operational entity, was permitted more leniencies with respect to its compliance with the standards contained in the VFM. The paramount importance of debt as it relates to the economy and, more specifically to individual citizens, was downplayed. The DoF was also permitted to contradict itself in several instances. For example, the DoF report stated that the personnel are highly "committed," yet in the highly specialized, top-level Risk Management division of the DoF, "the unit's turnover in the last year was 100 percent" (p. 8-5). "Three of the [four] specialists left for private industry" according to what was reported in the audit document (p. 8-21). Certainly, this makes an outsider question exactly how commitment is measured and, in turn, how carefully the audit team is assembling the logic behind their statements.

The RCMP has been remiss in establishing systems and procedures that were recommended by the OAG's report over a decade ago. Their review in this April 2000 audit series excoriates the department for its lack of follow-up. The audit shows the RCMP in a harsh light - citing very real consequences due to their inaction. It is also interesting to note that the 1990 predecessor document to this report generated little or no action on the part of the RCMP. Ten years elapsed and the OAG continued to cite the RCMP for recurring infractions. If, as Carolyn Miller (1984) notes in her 
article "Genre as Social Action," "we understand genres as typified rhetorical actions based in recurrent situations" (Bazerman, 2000), then a form of social action should have occurred within the RCMP. As nothing was done, the OAG's report of 1990 could be deemed a failure for its inability to create sufficient momentum to perpetuate change. On the other hand, the report could reflect a specialized instantiation of the report genre whereby action in governmental organizations becomes less exigent due to how information is shaped and presented towards the end goal of ensuring the message is correct.

The review time lines between the RCMP and the DoF also seem at odds with the guidelines and deliver a disturbing message. The concerns with respect to the RCMP identified in the report of April 2000 are almost identical to those in the 1990 document. These concerns were labeled as serious ten years prior and the level of severity had not declined in the ensuing decade. Meanwhile, Canada's debt management strategy had to undergo radical change to accommodate a surplus situation. The DoF had been audited every five years to ensure sufficient mechanisms were in place. Naturally, the question to ask relates to why the RCMP was not reviewed with greater regularity. Are Canadian citizens to conclude that money is more important than possibly saving human lives via efficient law enforcement methodologies?

The reports from the OAG comprise a vast array of topics and attempt to present complex information to a mass audience. Visually, the reports appear uninviting and daunting-their numbered paragraphs and crowded pages undoubtedly reduce the interest levels of many readers. For most readers though, a single report will have an authority sufficient for their need of determining how appropriately the government's operations are run. Only when the reports are compared does that authority come into question.

However, in considering these reports as public documents, it becomes necessary to see how the public might not be aware of the influences of audit policy-as exercised by the VFM - in the creation of the report documents. The very word 'audit' infers an impartial and unbiased assessment; therefore, the neutrality and objectivity of OAG reports is undoubtedly assumed, especially by a public or lay readership. Without assessing the VFM and understanding its influence, the audience remains unaware that the information they are reading has been subject to various constraints, filtered through multiple levels of government hierarchy and finally delivered in a form that may not encourage comprehension.

\section{Conclusion}

While the documents examined here were products of an audit in 2000 , they afford a look into how government documents are created and the way these documents are shaped to send their message to a readership. As with all institutions striving for 
quality operations and best practices, the OAG's guidance with respect to audits is continually evolving, and in 2004, the successor to the Value-for-Money Audit Manual, the Performance Audit Manual (PAM), was released. Many of the phrases cited in this analysis of the 2000 VFM no longer appear in the revised PAM; for example, ensuring "the message is right," checking the "compliance of the chapter with the reporting standards," and ensuring "the messages they contain are consistent with previous Office positions" have been removed. Considering the prescriptive intent of this type of phraseology, their removal may strive towards the production of clearer, more honest publications.

In addition, many of the areas noted in this analysis were identified as problematic by audit industry professionals. Four years later on February 4, 2004, an international peer review of the OAG praised the operation for many of its sound practices and attention to quality. Additionally, the review team indicated, under the section "Opportunities for Improvement," the following:

- consideration could also be given to how to design recommendations that are clear about the action departments need to take, and are focused on causes, results, and departments' performance.

- doing more to show that the VFM audits make a difference, for example in following-up on not only where recommendations have been implemented but what they have achieved in terms of improved performance.

- earlier consideration of the areas for recommendation in the audit cycle could enable audit teams to focus on beneficial change and discuss with departments at an earlier stage.

- reports could benefit from a wider use of graphics and illustrations to present complex numerical data and other information

- expanding the training and guidance available to VFM staff on methodologies and presenting report data.

- improving the presentation of reports both in terms of use of graphics and tables to present complex numerical and financial data to enliven the chapters. The review team noted the need to make audit report recommendations clearer and word them as action statements with concretely defined completion criteria. In cases such as the 1990 and 2000 evaluations of the RCMP- where little to no improvement occurred - the necessity of such a recommendation is evident. Additionally, the team suggested that the OAG work towards developing better graphics and visuals for its reports-a step that will undoubtedly help to make these documents more informative to their readership.

As a review of a specific instance of a government document, federal audit reports of Canada's operations provide insight into how appraisals of operations become both parliamentary and public documents. The two reports examined here in conjunction 
with the 2000 Value-for-Money Audit Manual demonstrate how reporting standards can vary and how the messages released by the Office of the Auditor General become shaped to ensure the message is right.

\section{References}

Bazerman, C. (2000). Singular utterances: Realizing local activities through typified forms in typified circumstances. In A. Trosborg (Ed.), Analysing professional genres (pp. 25-40). Philadelphia: John Benjamin BV.

Foss, S. K. (2004). Framing the study of visual rhetoric: Toward a transformation of rhetorical theory. In C. A. Hill \& M. Helmers (Eds.), Defining visual rhetorics (pp. 303-313). Mahwah: Lawrence Erlbaum Associates.

Herrington, T. K. (1995). Ethics and graphic design: A rhetorical analysis of the document design in the report of the Department of the Treasury on the Bureau of Alcohol, Tobacco, and firearms investigation of Vernon Wayne Howell also known as David Koresh. IEEE Transactions on Professional Communication, 38 (3), 151-157.

Johnsen, L. (2000). Rhetorical clustering and perceptual cohesion in technical (online) documentation. In A. Trosborg (Ed.), Analysing professional genres (pp. 193-206). Philadelphia: John Benjamin BV.

Killingsworth, M. J., \& Palmer, J. S. (1992). The environmental impact statement and the rhetoric of democracy. Ecospeak: Rhetoric and environmental politics in America (pp. 163-191). Carbondale: SIU Press.

Kleimann, S. (1993). The reciprocal relationship of workplace culture and review. In R. Spilka (Ed.), Writing in the workplace (pp. 111-123). Carbondale: Southern Illinois University Press.

Kostelnick, C., \& Hassett, M. (2003). Shaping information: The rhetoric of visual conventions. Southern Illinois University.

Miller, C. (1984). Genre as social action. Quarterly Journal of Speech, 70, 151-167.

Office of the Auditor General of Canada. (2000). Chapter 8: Department of finance, managing Canada's debt: Facing new challenges. 2000 Report of the Auditor General of Canada. (OAG/CESD). Ottawa, ON: Canada.

Office of the Auditor General of Canada. (2000). Chapter 7: Royal Canadian Mounted Police, services for Canada's law enforcement community. 2000 Report of the Auditor General of Canada. (OAG/CESD). Ottawa, ON: Canada.

Office of the Auditor General of Canada. (2000). Value-for-money audit manual. (OAG/CESD). Ottawa, ON: Canada. 
Office of the Auditor General of Canada. (2004). International peer review of the value for money audit practice of the office of the auditor general of Canada. Opportunities for improvement. Caroline Mawhood: Review Leader. Retrieved October 27, 2006, from http://www.oag-bvg.gc.ca/domino/other.nsf/html/ 200402peer_e.html

Office of the Auditor General of Canada. (2004). Performance audit manual. (OAG/ CESD). Ottawa, ON: Canada.

Paré, A. (1993). Discourse regulations and the production of knowledge. In R. Spilka (Ed.), Writing in the workplace. Carbondale: Southern Illinois University Press.

Rude, C. D. (1995). The report for decision-making: Genre and inquiry. Journal of Business and Technical Communication, 9 (2), 170-205.

Schriver, K. A. (1997). Dynamics in document design. New York: John Wiley \& Sons.

Smart, G. (1993). Genre as community invention. In R. Spilka (Ed.), Writing in the workplace (pp. 124-140). Carbondale: Southern Illinois University Press.

The Department of the Secretary of State of Canada. (1985). The Canadian style. Toronto: Ministry of Supply and Services Canada. 